\title{
Harvest Date and Storage Quality of Herbaceous Perennials
}

\author{
Anne M. Hanchek ${ }^{1}$ and Arthur C. Cameron \\ Department of Horticulture, Michigan State University, East Lansing, \\ MI 48824
}

\author{
Additional index words. Coreopsis, Dicentra, Geum, Gypsophila, Iberis, regrowth, cold \\ storage
}

\begin{abstract}
The effect of harvest dates between September and December on regrowth after storage of field-grown Coreopsis grandiflora Hogg x Sweet 'Sunburst' and 'Sunray', Geum quellyon Sweet 'Mrs. Bradshaw', Gypsophila paniculata L. 'Snowflake', Iberis sempervirens L. 'Snowflake', and Dicentra spectabilis (L.) Lem. crowns was determined. After 0 to 7 months of storage at $\mathrm{OC}$, stored crowns were repotted and grown in a greenhouse. Plants from later harvests were of higher quality than those from earlier harvests, showing higher rates of survival after longer storage periods, less mold development in storage, and stronger regrowth after storage. Late field harvest is recommended for optimum storage quality.
\end{abstract}

An area of particularly rapid horticultural expansion is the sale of herbaceous perennials (Rhodus, 1993). The surge in popularity of herbaceous perennials places greater demands upon growers to supply high-quality plants. A common Upper Midwest commercial production scheme is to field-plant seeds or cuttings in the spring, lift and divide the crowns in the fall, and store them bareroot in polyethylenelined crates at -2 to $+2 \mathrm{C}$ for several months until shipped (Heiden and Cameron, 1986; Lake et al., 1982).

Commercial growers have few researchbased recommendations to guide them in deciding when to harvest (Langhans and Weiler, 1967; Mahlstede and Fletcher, 1960). Recommendations do not address harvest date as a factor in the storage of herbaceous perennials (Hardenburg et al., 1986), although Mahlstede and Fletcher (1960) stressed the importance of maturity for successful handling of all nursery stock. The experience of Upper Midwest growers indicates that most plants harvested before November in USDA Zone 5 (U.S. Dept. of Agriculture, 1990) generally do not store well and lead to poorer product and loss of revenues and reputation. Certain perennials that are summer-dormant, such as bearded iris (Iris L. section Iris L.) and oriental poppy (Papaver orientale L.), can be lifted early in the fall (Armitage, 1989).

Extensive work on strawberry (Fragraria $\times$ ananassa Duch.) crowns indicated that de-

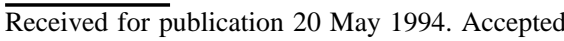
for publication 23 Jan. 1995. We gratefully acknowledge Walters Gardens, Zeeland, Mich., for donating plants. Research taken from a dissertation by A.M.H. in partial fulfillment of the requirements for a $\mathrm{PhD}$ degree in horticulture. Minnesota Agricultural Experiment publication \#21190. The cost of publishing this paper was defrayed in part by the payment of page charges. Under postal regulations, this paper therefore must be hereby marked advertisement solely to indicate this fact.

${ }^{1}$ Dept. of Horticultural Science, Univ. of Minnesota, St. Paul, MN 55108.

HortSCienCE, Vol. 30(3), June 1995 stored for shorter periods; for example, if removed and potted on $8 \mathrm{Jan} .1986$, individual crowns had been stored for 6 to 17 weeks; if removed and potted on 9 Apr. 1986, they had been stored for 19 to 30 weeks.

Upon removal from storage, 10 plants per species from each harvest were evaluated for obvious surface mold growth, using a 1 to 4 scale $(1=0 \% \leq 25 \%$ surface covered with mold, $2=$ greater than or equal to $25 \% \leq 50 \%$ surface molded, $3=$ greater than or equal to $50 \% \leq 75 \%$ surface molded, and $4=$ greater than or equal to $75 \% \leq 100 \%$ surface molded). The crowns were then potted and placed in a cool greenhouse (19C day/12C night) under ambient light. At 3 and 4 weeks after potting, we measured plant height and evaluated regrowth using a 0 to 5 scale $(0=$ dead; $0.5=$ dormant buds; $1=$ emergent growth; $2=$ a few expanded leaves; $3=$ small plant with few shoots; $4=$ moderate-sized plant with strong growth; and $5=$ large plant with bushy, vigorous growth) following the rating scales of Maqbool (1986). The ratings at 3 and 4 weeks were averaged to give a mean regrowth rating for the treatment. Presence of vegetative buds, floral buds, or open flowers was noted. Since Iberis is a sub-shrub and plants were not pruned at harvest or potting, regrowth was defined as greening of existing foliage and extension of lateral branches; height during regrowth was not measured.

In 1986, first-year crowns of Coreopsis 'Sunray', Gypsophila 'Snowflake', and D. spectabilis were harvested weekly from 7 Oct. to $2 \mathrm{Dec}$. Twenty crowns per species were stored at $0 \mathrm{C}$, while 10 crowns per species were potted immediately. To avoid the variation in storage length in the 1985 experiment, we removed plants from the 1986 harvest from storage after 2 and 4 months from the date of harvest. Mold development and regrowth were evaluated as before in a cool greenhouse under ambient light, with one exception: Dicentra crowns were placed under $16 \mathrm{~h}$ of 147 $\mu \mathrm{mol} \cdot \mathrm{m}^{-2} \cdot \mathrm{s}^{-1}$ supplemental light during the day.

The data for each year were analyzed as completely randomized designs (Milliken and Remmenga, 1989). Least significant differences between treatment means were calculated as indicators of variability at $\alpha=0.05$ with $\mathrm{n}=5$ replications per treatment cell (1985, no storage) or $\mathrm{n}=10$ (all others).

Soil temperature at a 10-cm depth at 10:00 $\mathrm{AM}$ at 10 random locations in each species' harvest site was measured in both years on the date of harvest. Daily weather records for soil temperatures at a $10-\mathrm{cm}$ depth in uncovered soil (Michigan State Univ. Agricultural Weather Service, 1985, 1986) also were obtained from the Trevor Nichols Experimental Farm in Fennville, Mich., located 20 miles south of Zeeland. Records were not kept for soil temperatures after 17 Oct. 1985 and after 31 Oct. 1986.

\section{Results}

Soil conditions. Soil temperature at a 10$\mathrm{cm}$ depth during September, October, and November declined from near 20 to $2 \mathrm{C}$ for 
Table 1. Growth form and hardiness of herbaceous perennials used in harvest date studies.

\begin{tabular}{|c|c|c|c|c|}
\hline $\begin{array}{l}\text { Botanical } \\
\text { name }\end{array}$ & $\begin{array}{c}\text { Common } \\
\text { name }\end{array}$ & $\begin{array}{c}\text { Root } \\
\text { system }\end{array}$ & $\begin{array}{l}\text { Crown condition } \\
\text { in storage }\end{array}$ & $\begin{array}{r}\text { USDA zones } \\
\text { of hardiness }\end{array}$ \\
\hline \multicolumn{5}{|l|}{$\overline{\text { Coreopsis grandiflora Hogg X Sweet }}$} \\
\hline 'Sunburst' and 'Sunray' & Coreopsis & Fibrous & Trimmed leafy rosette & $4-9$ \\
\hline Dicentra spectabilis (L.) Lem. & Old-fashioned bleeding heart & Tuberous & Dormant buds on tuberous root & $2-9$ \\
\hline Geum quellyon Sweet 'Mrs. Bradshaw' & Avens & Fibrous & Trimmed leafy rosette & $5-7$ \\
\hline Gypsophila paniculata L. 'Snowflake' & Baby's breath & Fleshy tap & Dormant buds on fleshy taproot & $3-9$ \\
\hline Iberis sempervirens L. 'Snowflake' & Candytuft & Fibrous & Leafy sub-shrub & $3-9$ \\
\hline
\end{tabular}

both harvest seasons (Fig. 1). In the sandy loam fields, soil moisture varied between September and November from $5 \%$ to $12 \%(\mathrm{w} / \mathrm{w})$ in response to temporary conditions such as rainfall, snow, cultivation, and cloud cover (data not shown). No relationship between soil moisture content and storage behavior could be established.

Coreopsis. Mold on stored Coreopsis 'Sunburst' crowns decreased with later harvests $(r=-0.87, \alpha=0.0001)$ and was barely detectable for the final three harvest dates. Crowns lifted anytime during the harvest season in 1985 and potted immediately always developed vigorous new basal growth (Fig. 2). However, most plants harvested before 31 Oct. did not survive 11 weeks or more of storage. All crowns harvested 14 Nov. or later survived at least 19 weeks at $0 \mathrm{C}$. Regrowth of stored crowns improved dramatically with November harvests. Overall, the most vigorous plants were those harvested in late November and stored 1 to 5 months.

Coreopsis 'Sunray', harvested in 1986, did not develop mold growth in storage and $100 \%$ of the crowns survived (Fig. 3). Crowns potted the day of harvest regrew, but were generally rated lower than those stored for 2 or 4 months. For 'Sunray', the most highly rated plants were those harvested in mid-October or later, and stored 4 months. Coreopsis is an obligate long-day plant (Dammann and Lyons, 1993), yet neither cultivar flowered within 8 weeks of potting, even those plants exposed to ambient long days in the greenhouse in spring.

Geum. Stored crowns were rarely free of mold (Fig. 2). Crowns of early harvests and the long storage periods showed more mold growth than those harvested later and stored less long. Survival was not related to mold growth. Death in storage was $\geq 25 \%$ only for September harvests stored for 7 months or more. Crowns potted the day of harvest survived and regrew well. Stored plants did not regrow as well unless harvested in November. No plants flowered within 8 weeks of potting.

Gypsophila. Gypsophila roots harvested in Sept. and Oct. 1985 had more mold and lower survival the longer they were stored at $0 \mathrm{C}$ (Fig. 2). October- and November-harvested plants survived 10 to 14 weeks (planting date 8 Jan.) and 19 to 22 weeks (planting date 9 Apr.) of storage, respectively. Regrowth was better for November- than October-harvested crowns (Fig. 2). Unstored plants generally regrew well.

In 1986, results were quite different. The regrowth of plants harvested in October or November and stored for 4 months was consistently high (Fig. 3). Two months' storage produced good plants only from November

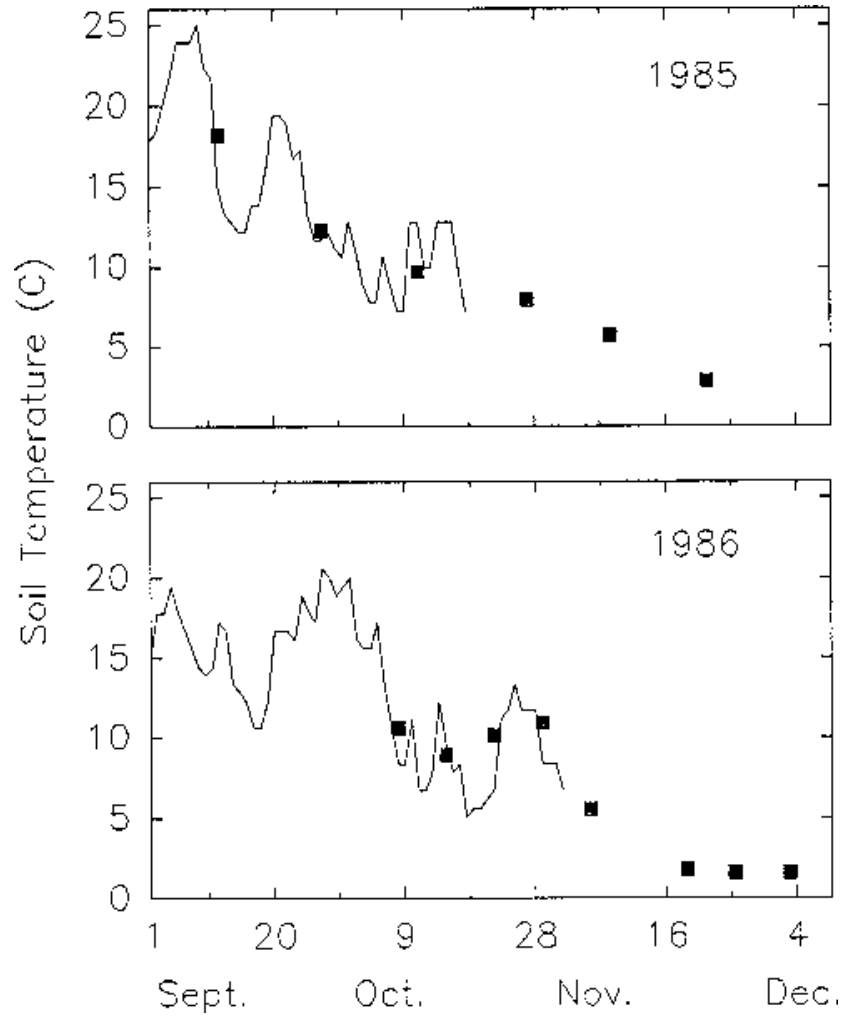

Fig. 1. Minimum daily soil temperatures at a10-cm depth at (-) Trevor Nichols Experimental Farm, Fennville, Mich., and average soil temperatures at a 10-cm depth at 10:00 AM in (耳) perennial fields, Zeeland, Mich. Zeeland 1985 standard error of the mean $=0.3$; Zeeland 1986 standard error of the mean $=0.4$.
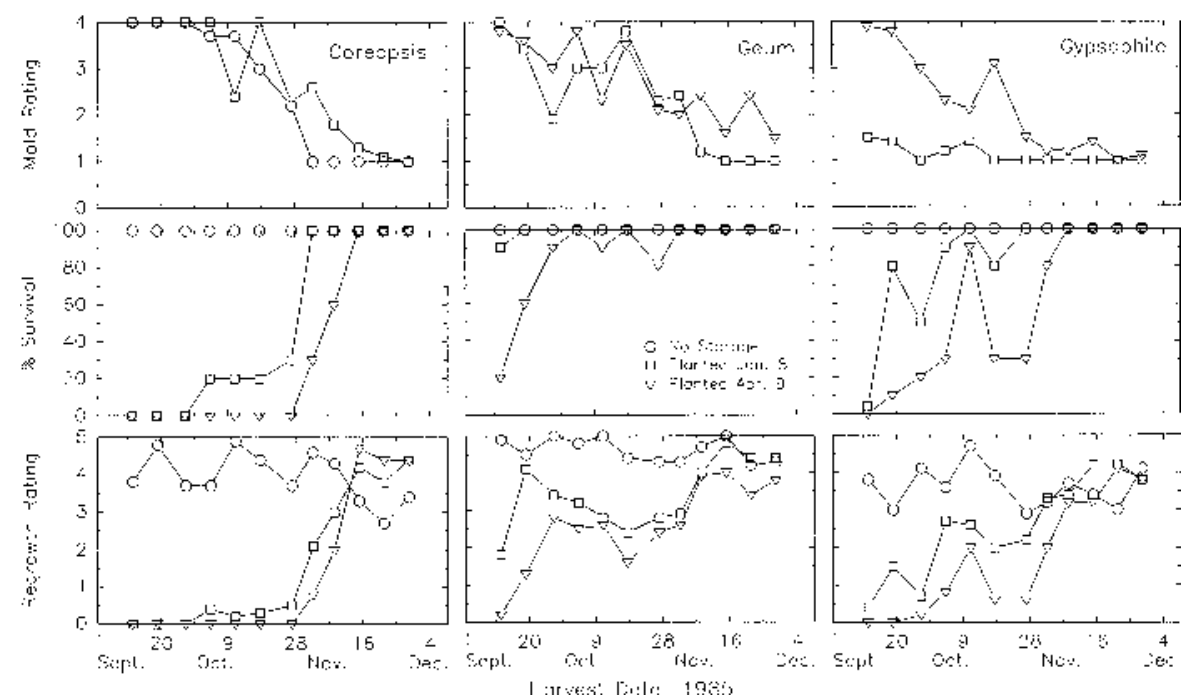

Fig. 2. Effect of harvest date and date of planting after various lengths of storage at 0C on condition and regrowth of Coreopsis lanceolata 'Sunburst', Geum quellyon 'Mrs. Bradshaw', and Gypsophila paniculata 'Snowflake' in 1985. Crowns were either planted immediately upon harvest or on 8 Jan. or 9 Apr. Mean mold rating scale at potting: $1=$ no to little observable mold growth to $4=$ at least $75 \%$ covered with fungal growth; $\mathrm{LSD}_{0.05}=0.5$. Mean regrowth 4 weeks after potting: $0=$ no regrowth to $5=$ excellent regrowth; $\mathrm{LSD}_{0.05}($ no storage $)=1.0, \mathrm{LSD}_{0.05}($ with storage $)=0.9$. 

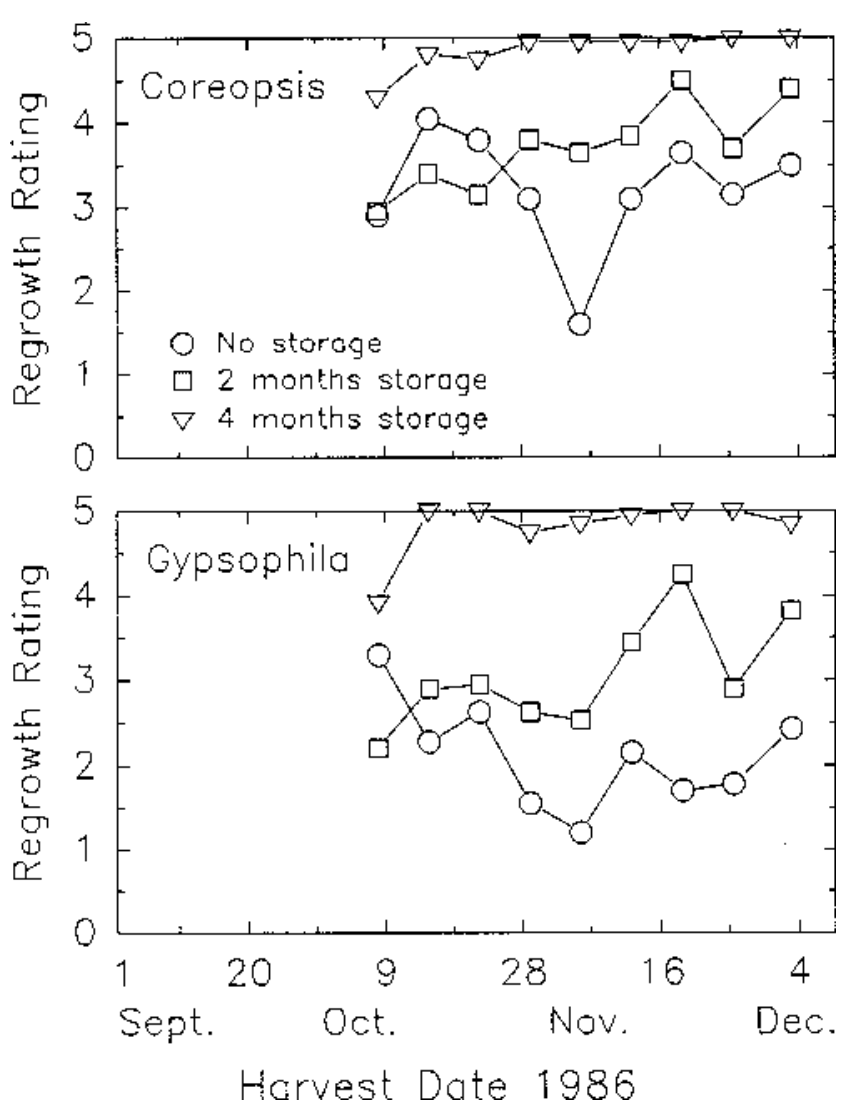

Fig. 3. Effect of harvest date and length of storage at $0 \mathrm{C}$ on regrowth of Coreopsis grandiflora 'Sunray' and Gypsophila paniculata 'Snowflake' in 1986. Mean regrowth 4 weeks after potting: $0=$ no regrowth to 5 = excellent regrowth; Coreopsis, $\mathrm{LSD}_{0.05}=0.5 ;$ Gypsophila, $\mathrm{LSD}_{0.05}=0.8$. For both species, all of the plants survived.

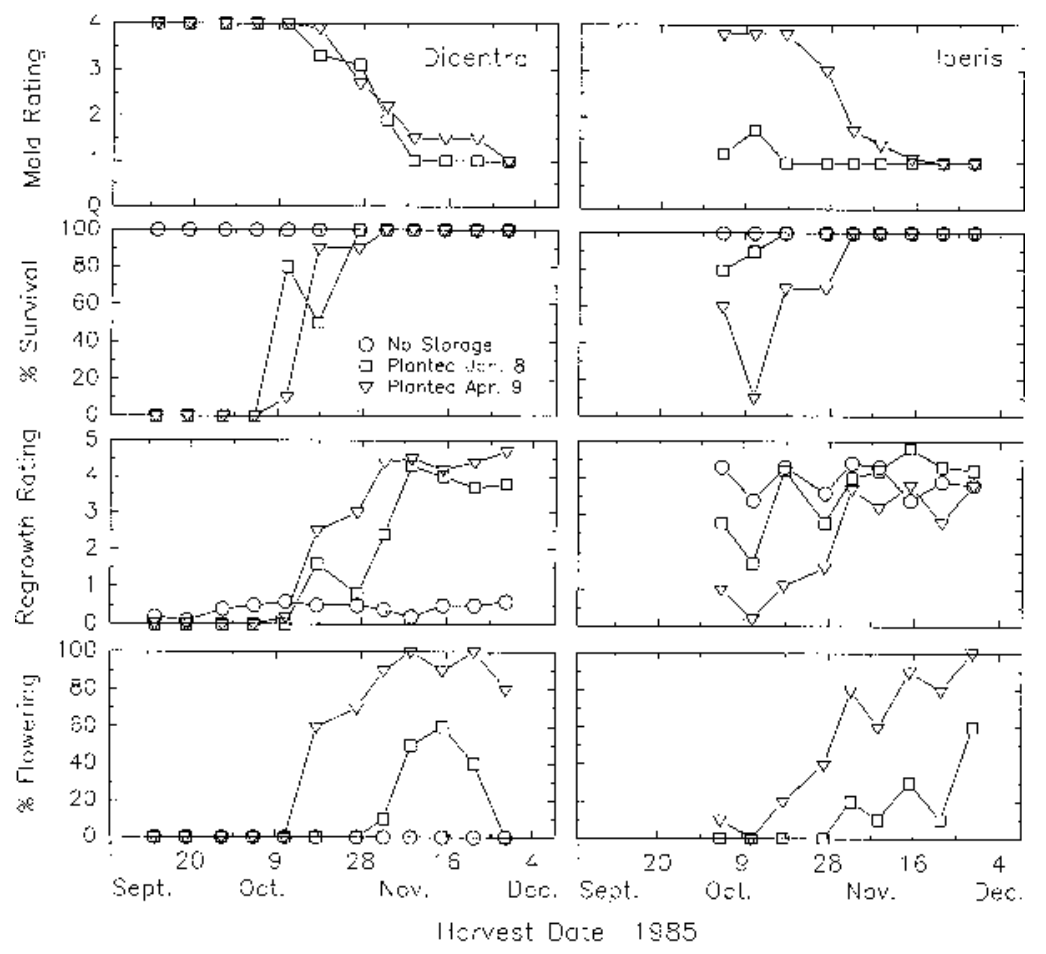

Fig. 4. Effect of harvest date and date of planting after various lengths of storage at $0 \mathrm{C}$ on condition and regrowth of Dicentra spectabilis and Iberis sempervirens 'Snowflake' in 1985. Crowns were either planted immediately upon harvest or on $8 \mathrm{Jan}$. or 9 Apr. Mean mold rating after potting: $1=$ no to little observable mold growth to $4=$ at least $75 \%$ covered with fungal growth; $\mathrm{LSD}_{0.05}=0.5$. Mean regrowth 4 weeks after potting where $0=$ no regrowth to $5=$ excellent regrowth; no significant differences between no-storage means, $\mathrm{LSD}_{0.05}$ (with storage) $=0.9$. Percent crowns flowering within 4 weeks after potting. harvests, while unstored roots did not regrow well if harvested after mid-October. No plants flowered within 8 weeks of potting in either year, despite being an obligate long-day plant (Shillo, 1985) and experiencing ambient daylengths in excess of $12 \mathrm{~h}$ when potted in spring.

Dicentra. Dicentra crowns harvested before 10 Oct. 1985 became heavily molded and rotted in storage, and did not survive (Fig. 4). Plants harvested on or after 7 Nov. showed little mold development in storage and had excellent regrowth regardless of storage duration. Plants potted at harvest survived, but usually did not regrow, except for a few plants from the latest harvests in 1986. Vegetative buds were visible on many plants at time of harvest.

In 1986, little mold developed in storage and all plants survived (data not shown). Regrowth of stored plants, however, was similar to that of the previous year (Fig. 5). In both years, late harvests and long storage at $0 \mathrm{C}$ produced more highly rated plants that were also more likely to flower.

Iberis. Foliage of October-harvested Iberis was heavily molded after 6 months at $0 \mathrm{C}$ (Fig. 4). Surviving individuals from these treatments regrew poorly. Shorter storage periods and later harvests produced more highly rated plants that were free from mold. Unstored Iberis from all harvests grew well in the greenhouse but did not flower. Flowering was best for plants harvested in November and stored for 5 months.

\section{Discussion}

Companies frequently turn back newly arrived shipments of herbaceous perennials because inspectors see surface molds on the plants. High surface mold ratings ( 3 or higher) were associated with poor survival, regrowth, or both in our tests. However, a low mold rating or lack of mold was not always a good predictor of subsequent regrowth, since plants free of mold did not always grow well when planted. In many cases, dead or dying plants had rotted in storage, unrelated to the presence of surface mold. Surface molds commonly present on stored herbaceous perennials are typically secondary or superficial pathogens (Hanchek et al., 1989). Fungicides are often phytotoxic (Maqbool, 1986) and give variable control. Our study showed that mold on stored perennials can be reduced by late harvest.

There were some striking differences between the 1985 and 1986 seasons. All three species harvested in 1986 (Dicentra, Gypsophila, and Coreopsis 'Sunray') supported only minor mold growth in storage compared to 1985. Survival rates, on the whole, were better for 1986 harvests as well. Regrowth ratings for stored Gypsophila and Coreopsis 'Sunray' were consistently high for Oct. 1986 harvests, unlike for the previous year (Fig. 3). These differences might have been related to overall improved plant quality due to weather conditions, or to lack of pathogen inoculum in the 1986 field, or, for Coreopsis, cultivar-specific responses. 

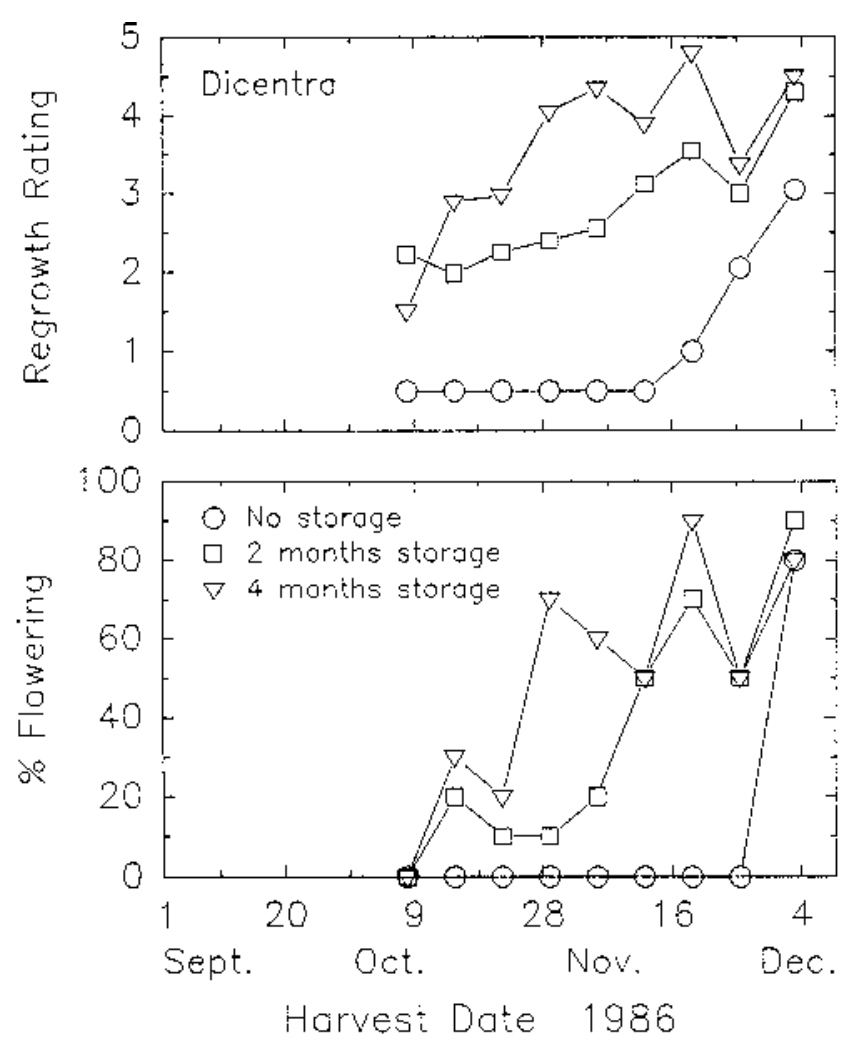

Fig. 5. Effect of harvest date and length of storage at $\overline{0} \mathrm{C}$ on regrowth of Dicentra spectäbilis in 1986. Mean regrowth 4 weeks after potting: $0=$ no regrowth to $5=$ excellent regrowth; $\mathrm{LSD}_{0.05}=1.0$. Percent crowns flowering within 4 weeks after potting.

At some point during the harvest season, plants gained the ability to remain undamaged by long storage. Generally, the observed changes in plant response to storage in 1985, whether in mold rating, regrowth, height, or crown bud length, occurred in mid-October at the same time that soil temperatures at the 10cm depth dropped below 10C. Similar changes were evident in Oct. 1986, when soil temperatures dropped earlier and stayed low for several weeks. Chilling is assumed to drive the hardening process (Weiser, 1970), but most authors have worked with woody plants that carry aerial perennating buds. Herbaceous perennials may primarily respond to the temperature of the soil surrounding their terrestrial buds. Hardening in response to soil temperature may be the reason why little or no mold was found on stored crowns harvested in 1986. The change from "unstorable" to "storable" may have taken place in the first week of the 1986 experimental harvest period. The most striking differences by far in survival, mold problems, growth rate, and flowering were seen in Dicentra crowns from early vs. late harvests. These differences support the conclusion that fully hardened material was the best for storage, and further document the fact that Dicentra has an absolute chilling requirement to overcome dormancy (Hanchek, 1989; Lopes and Weiler, 1977).

Our results suggest that the critical soil temperature for field hardening of the five herbaceous perennials studied was below 10C. However, controlled chilling of bareroot plants at $0 \mathrm{C}$ in dark storage did not fully replace field chilling for early harvested plants. This observation is based on the fact that plants from the first harvest in 1985, potted 8 Jan. 1986 after storage for 17 weeks at $0 \mathrm{C}$, did not respond the same as plants from the last harvest in 1985 , potted 9 Apr. 1986 after storage for 18 weeks at 0C. Late-harvested plants consistently received higher regrowth ratings after storage. Other seasonal factors, such as diurnal air temperature cycles, decreasing daylength, and date and intensity of frosts, may play a role in field hardening.

\section{Literature Cited}

Anderson, H.M. and C.G. Guttridge. 1975. Survival and vigour of cold-stored strawberry runner plants after different lifting dates, storage temperatures and pre-storage treatments. Expl. Hort. 27:48-57.

Armitage, A.M. 1989. Herbaceous perennial plants. Varsity Press, Athens, Ga.

Cameron, A.C. and M. Maqbool. 1986. Postharvest storage of bare-root hardy perennials: The relation of water loss to storage survival. Acta Hort. 181:323-329.

Damman, M.P. and R.E. Lyons. 1993. Juvenility, flowering, and the effects of a limited inductive photoperiod in Coreopsis grandiflora and $C$. lanceolata. J. Amer. Soc. Hort. Sci. 118:513518.

Hanchek, A.M. 1989. Growth and development of Dicentra spectabilis in relation to storage temperature and harvest date. PhD Diss., Michigan State Univ., East Lansing.

Hanchek, A.M., K. Everts, M. Maqbool, and A.C. Cameron. 1989. Storage molds of herbaceous perennials. J. Environ. Hort. 8:29-32.

Hardenburg, R.E., A.E. Watada, and C.Y. Wang. 1986. The commercial storage of fruits, vegetables, and florist and nursery stocks. U.S. Dept. of Agr. Hdbk. 66 (revised).

Heiden, R. and A.C. Cameron. 1986. Bare-root perennials require cautious handling. Amer. Nurseryman 163(7):75-88.

Lake, B., C. Noble, and D.F. Hamilton. 1982. Growing herbaceous perennials. Amer. Nurseryman 155(7):81-85.

Langhans, R. and T. Weiler. 1967. Factors affecting flowering, p. 37-46. In: D. Kiplinger and R. Langhans (eds.). Easter lilies. Prepared for the New York and Ohio Lily Schools, Feb. 1967.

Lopes, L.C. and T.C. Weiler. 1977. Light and temperature effects on the growth and flowering of Dicentra spectabilis (L.) Lem. J. Amer. Soc. Hort. Sci. 102:388-390.

Mahlstede, J.P. and W.E. Fletcher. 1960. Storage of nursery stock. Amer. Assn. Nurserymen, Washington, D.C.

Maqbool, M. 1986. Postharvest handling and storage of bare-root herbaceous perennials, MS Thesis, Michigan State Univ., East Lansing.

Michigan State Univ. Agricultural Weather Service. 1985, 1986. Weather data listing for Trevor Nichols Experimental Farm, Fennville, Mich. Dept. of Entomology, Michigan State Univ., East Lansing.

Milliken, G.A. and M.D. Remmenga. 1989. Statistical analyses and the personal computer. HortScience 24:45-52.

Rhodus, T. 1993. Views on management. Perennial Plants n.s.1(3):26-34 (Summer 1993).

Ritchie, G.A., J.R. Rodin, and N. Kleyn. 1985. Physiological quality of lodgepole pine and interior spruce seedlings: Effects of lift date and duration of freezer storage. Can. J. For. Res. 15:636-645.

Shillo, R. 1985. Gypsophila paniculata, p. 83-87. In: A. Halevy (ed.). CRC handbook of flowering. vol. 3. CRC Press, Boca Raton, Fla.

Stone, E.C., J.L. Jenkinson, and S.L. Krugman. 1962. Root-regenerating potential of Douglasfir seedlings lifted at different times of the year. For. Sci. 8:288-297.

U.S. Department of Agriculture. 1990. USDA hardiness zone map. U.S. Dept. of Agr., Agr. Res. Serv., Publ. 1475.

Voth, V. and R.S. Bringhurst. 1970. Influence of nursery harvest date, cold storage, and planting date on performance of winter planted California strawberries. J. Amer. Soc. Hort. Sci. 95:496500.

Weiser, C.J. 1970. Cold resistance and acclimation in woody plants. HortScience 5:403-411. 